\title{
The Effects of Leadership Styles on Employee Motivation in Auditing Companies in Ho Chi Minh City, Vietnam
}

\author{
Mai Ngoc Khuong and Dang Thuy Hoang
}

\begin{abstract}
This research chose auditing field as a case study to investigate and evaluate the overall leadership styles effects on employee motivation. The research applied quantitative method with a sample size of 320 respondents - auditors working in Ho Chi Minh City. The independent variables were task-oriented leadership, relation-oriented leadership, change-oriented leadership, charismatic leadership, participative leadership, ethical leadership, ethic-based contingent reward leadership and autocratic leadership and employee motivation was the dependent variable. These independent variables could explain $64.5 \%$ of the variation within employee motivation. This result implied a strong influence of leadership styles in retaining and developing employee motivation. In addition, this research indicated that charismatic leadership, relation-oriented leadership, and ethic-based contingent reward leadership were positively associated with employee motivation.
\end{abstract}

Index Terms-Auditing field in Ho Chi Minh City, auditors, employee motivation, leadership styles, leadership behaviors.

\section{INTRODUCTION}

In today's competitive workplace, managers should equip themselves with leadership orientation and employee behaviors knowledge because of some following reasons. Doing business in a competitive environment, regardless of the field of production or service, require leaders to have a clear vision and direction to maintain and develop the company. To reach business success, there are several key factors such as: leadership skills, environment impacts and the most important element are human resources.

According to [1], in the current business environment, organizations in all industries are experiencing a rapid change, which is accelerating at an enormous speed. Hence, knowledge and understanding of inner strengths and weakness of the people in the organization is very useful for manager/company success. Human resources management theories assert that employees are indeed valuable because they will create values for firms. Thus, [2] said that business has come to realize that the motivated, stable and numerable workforce can deliver powerfully to the survival of company.

Ho Chi Minh City (HCMC) is a young and dynamic location that attracts various different types of business to operate; and when economic-society reach a higher level in development, the financial statements of businesses or organizations must be transparent and must be audited by auditing firms. In other words, all business must inform about

Manuscript received April 29, 2015; revised August 21, 2015.

M. N. Khuong and D. T. Hoang are with the School of Business, International University, VNU-HCM, Vietnam (e-mail: mnkhuong@hcmiu.edu.vn,dthoang11@gmail.com). their operation, procedure in order to provide sufficient information to government agencies, investment partners, and customers, etc. Because of positive change in economic policies of Vietnam, multilateral investments come from not only domestic but also overseas investors. When foreign investors intend to invest, their first necessary demanding is a financial statement audit confirmation of the enterprises. In addition, administrators and other managers in company also need truthful information on the financial disclosure table to take decisions at every stage of management, directing and managing the business operations. Consequently, for any different types of economies, auditing becomes as an indispensable needs. However, in Viet Nam in general and especially in Ho Chi Minh City, auditing industry and auditing firms are considered relatively young in both quantity and quality. There are only about 165 auditing firms compared to the needs of thousands business that require auditing service annually for their companies. The large difference in the quality of services among audit firms led to the common ground of this service is not high. Nearly 1.500 people were certified auditors mainly concentrated in the large audit firms; in 2012, there were only 20 firms in Vietnam belong to the international audit firms [3]. Thus, this research aim at 1) finding out criteria of leadership styles that would be suitable for auditor working in HCMC, 2) identifying important leadership styles that have the most influence to employee motivation, 3) recommending improving and developing suggestions for leaders to better off its field based on the results and findings of the research.

\section{LITERATURE REVIEW}

\section{A. Employee motivation}

Nowadays, employee motivation is considered as one of the most vital parts in reaching the success and prosperity of business in such a dynamic and fierce market competition. According to [4], employee motivation is a set of energetic forces, including internal factors of each individual as well as external factors, for example, job characteristics, individual differences and organizational practices. In other words, employee motivation should be a complete combination of employee's needs and expectations that created from work, and the workplace factors that enable employee motivation. Satisfying those factors to increase employee motivation is absolutely a huge challenge for every employer. As a result, each leader/manager has to understand his or her employees' requirements, needs, or expectations and generate a suitable work environment to motivate employees [5]. Nevertheless, within all the functions a leader performs, motivating 
employees is assumed as the most complex task. This is because in the workplace what motivates employees, changes constantly [6].

According to [7], key factors contributing to employee motivation are employees' needs, working environment, responsibilities, supervision, fairness and equity, effort, employee's development and feedback and rewarding. [5] said that encouraging employees for achieving their goals is important in creating an enjoyable work environment. Appreciation goes with positive feedback; verbal praise can improve remarkably employee motivation. In addition, employees should be invited to share their experiences in, and co-workers' contributions toward, accomplishing the goals. About work environment and tasks, [7] suggested workplace, which brings productive, respectful, provides a feeling of inclusiveness and offers a friendly atmosphere should be established. [7] also suggested that rewards lead to higher level of motivation as well as performance. To influencing individual or group behaviors, rewards are management tools that contribute positively to firm's effectiveness. Common types of rewards are used by most of businesses, namely: payment, promotion, bonuses to motivate and encourage high-level performances of employees [8]. Nonetheless, the degree of employee motivation does not depend totally on money incentive; instead, there are many ways (as mentioned above) of increasing employees work motivation [9].

\section{B. Task Oriented Leadership}

Task oriented leadership is defined as the degree to which a leader set their followers roles, focuses on goal achievement, and establishes well-defined patterns of communication [10]. To put it more clearly, task oriented leadership will force their followers engage in top-down communication, explain what the follower is to do, as well as when, where, and how each function is accomplished. A task oriented leader focuses on providing structure to his employees and encourages them to complete their tasks at the first point [11]-[13]. In the provided structure, employees follow rules and procedures as established by the leader- resulting in strict guidance.

In recent years, The University of Michigan studies level of effectiveness of task oriented behaviors [14] involved "placing emphasis on planning, coordinating, and providing the resources needed by followers, including establishing goal-setting objectives for the followers". According to [15], the task-oriented leadership method is understood as problems focused, and change the situation positively by direct actions as well as reduce the amount of stress can be triggered; improve employee passion and high motivation to the job. Furthermore, task oriented strategies are parallel with better adjustment; produce more effectiveness and less depression [16], [17].

\section{Relation Oriented Leadership}

Relation oriented leadership illustrates the degree to which a leader show his attention and respect for their followers, looks out for their welfare, and expresses appreciation and support [18], [19]. Relation oriented leadership can create a stronger effect on employee motivation (both from job and leader motivation), comparing to task oriented leadership, which possesses a slightly stronger effect on leader performance. according to [20], [21], there are five specific relations oriented behaviors, which involve establishing an effective leadership style, including: a) Team building, b) consulting and delegating, c) Supporting, d) Developing, e) Recognizing. [22] proved that this leadership behavior would reduce employee turnover; moreover, [23] reported "the leadership behaviors of individualized support and intellectual stimulation resulted in higher levels of employee motivation".

\section{Change Oriented Leadership}

Change-oriented Leadership is defined as ability to get familiar with changes, making changes, and finding persuasive communications/methods to talk people about the change. Change oriented leadership behavior is primarily concerned with improving strategic decisions; adapting to change in the environment; increasing flexibility and innovation; making major changes in processes, products, or services; and gaining commitment to the changes [14]. Besides, a change- oriented leader has to understand the impacts of environment and find the creative/innovative ways regarding to strategies, products, manufacture to conform to the environment changes. Change oriented leadership requires a complete combination between integrating environmental inputs and variations in individual style. Meanwhile, change oriented leadership behavioral roles fall in four categories: (a) giving/seeking, (b) making decisions, (c) building relationships, and (d) influencing [24]. Change oriented behaviors are so helpful that gain significantly support from other followers as long as a leader has a high tolerance for risk, and ensure resistance to change does not stifle innovation. Importantly, [25] found significant positive correlations between change-oriented leadership style and employee motivation, organizational commitment, and evaluations of the leader's competence.

\section{E. Participative Leadership}

Participative leadership is well defined as producing decision making through motivating and encouraging employees join in making important decisions or at least all of those employees will share influence in decision- making [26]

Participative Leadership involved "managing the group meetings, influencing commitment and conformity, and assisting in conflict and communication issues". [14]. According to [27] "motivated employees usually believe that they are doing something worthwhile" and they believe that their participation is valued (group members depend on them and listen to their ideas). Thus, participative leadership style focuses on the intrinsic motivation of followers by enriching subordinates jobs through autonomy, variety and empowerment. Moreover, when employees participate in democratic decision making, they realize that their ideas are respected and considered by higher supervisors; they feel connected with the organization as if they are important parts in the company and try to reach maximum performance [27].

When implement Participative decision-making strategies in the workplace scenario, huge benefits offered for both leaders and employees: Increase employee's motivation [28]; Increase the level of innovation in the organizations [29]; Increase the quality of the decision [30]; Contribute to the quality of employee's work life [29]; Increase employees' motivation [31]; Increase the level of employee's commitment 
[32].

\section{F. Charismatic Leadership}

In term of charismatic leadership, a leader makes his/her followers believe that their leader has extraordinary leadership abilities. To be more specific, those leaders are "exceptionally expressive people, who employ rhetoric to persuade, influence and mobilize others" [33]. Charismatic leaders will have several common characteristics, clearly: they have vision and articulation, they are sensitive to their followers, they are willing to take risks, and they show unconventional behavior [34].

\section{G. Autocratic Leadership}

Autocratic leadership is demonstrated as a controlling, directive, or coercive leader, who seldom takes decisions basing on input from their subordinates [18]. Similarly, [35] described autocratic leadership, "which is based on personal dominance and authoritarian behavior that serves the self-interest of the leader, is self-aggrandizing and exploitative of others". "Autocratic leaders are domineering, controlling, and vengeful" [36]. An autocratic leader takes over the control in his/her office by dominating all the decisions and actions, giving clear/detail instruction and direction to the followers, force them what to do and how to carry out a task; all those mentioned actions will prevent employees from creativity and innovativeness. With subordinates, the leader communicates formally and in written form. The autocratic leadership style can be considered as a structure of pyramid in which a leader possesses the highest position on the top and the lowest position is for employees.

\section{H. Ethical Leadership}

Ref. [37] had defined ethical leadership as "the demonstration of normatively appropriate conduct through personal actions and interpersonal relationships, and the promotion of such conduct to followers through two ways communication, reinforcement, and decision making". As being an ethical leadership, [37] stated typical characteristics of ethical leaders including honest, trustworthy, fair and caring; transparent and engage in open communication, promoting and rewarding ethical conduct among followers. Such leaders make principled and fair choices and structure work environments justly.

To make people believe one leader behave ethically, [38] mentioned that a leader have to behavior virtuously to bring benefits for majority; protect him from doing evil acts or harmful impacts on others. The need for increased attention for integrity, a positive moral perspective, and ethical conduct in the leadership literature is also echoed in the recently developing stream of research on positive organizational operation, in work on spiritual leadership [39]

\section{Ethic Based Contingent Reward Leadership}

According to [33], contingent reward leadership is one of three facets of transactional leadership, 2 other facets including active management by exception, and passive management by exception. Hence, in the scope of the research, ethic based contingent reward leadership will be considered under ethics of transactional leadership. Main characteristics of transactional leadership include responsibility, fairness, honesty, and promise keeping. Hence, in transactional leadership "followers are motivated by leaders' promises, praises, and rewards or they are corrected by negative feedback, reproof, threats, or disciplinary actions" [40]. In transactional leadership, the ethical and moral legitimacy are described as "depends on (leaders) granting the same liberty's and opportunity's to others that one claims for oneself, on telling the truth, keeping promises, distributing to each what is due, and employing valid incentives or sanctions" [40]. To be more specific, the moral legitimacy of transactional leadership requires fairness; and in terms of the components of transactional leadership, contingent reward leadership illustrates the relationship between finish certain tasks/behaviors by the followers and receive rewards from leaders. Similarly, active management implies that the leader will implement punishment if followers fail to demonstrate required behaviors or complete certain tasks. Those components clearly explain "a form transactional leadership consistent with the underlying assumptions of a justice approach, namely separation, autonomy, and principles of fairness in exchange" [41].

Regarding to the above literature review, this study hypothesized that:

$\mathrm{H}_{1}$ : Task oriented leadership positively affects employee motivation.

$\mathrm{H}_{2}$ : Relation-oriented leadership positively affects employee motivation.

$\mathrm{H}_{3}$ : Change-oriented leadership affects employee motivation

$\mathrm{H}_{4}$ : Participative leadership positively affects employee motivation.

$\mathrm{H}_{5}$ : Charismatic leadership positively affects employee motivation.

$\mathrm{H}_{6}$ : Autocratic leadership negatively affects employee motivation.

$\mathrm{H}_{7}$ : Ethical leadership positively affects employee motivation.

$\mathrm{H}_{8}$ : Ethic based contingent reward leadership positively affects employee motivation.

\section{RESEARCh Methodology}

\section{A. Questionnaire Design and Data Collection}

With the aim of analyzing numerical data to exploring the effects of leadership styles on employee motivation, the quantitative approach was reasonably adopted. Also, because the objective of this research was finding the important leadership styles that impacted on employee motivation in the auditing companies, so the sample size must be larger to guarantee the representation of this research. Therefore, 320 questionnaire copies were conveniently and directly sent to auditors in Ho Chi Minh City.

Questionnaire design: A structured questionnaire was designed basing on the main concepts as well as important variables which were drawn from literature in the field of organizational behavior and leadership. The questionnaire was translated into Vietnamese and tested through a pilot study of 30 auditors ( $n=30)$ before officially sending to the 
target respondents $(n=320)$. The questionnaire was conveniently and directly sent to auditors working in Ho Chi Minh City. Most of the questions in the questionnaire used the five point Likert scale which was equivalent to " 1 = strongly disagree", " 2 = disagree", " 3 = neutral", " 4 = agree", and " $5=$ strongly agree".

\section{B. Factor Analysis and Reliability}

By applying Principle component analysis and Varimax rotation, all observed variables in the measurement scale were tested through two exploratory factor analyses (EFA) to discover their structure and convergence in the model. The first exploratory factor analysis was applied for the dependent variable, including nine items, and the other EFA was for the group of independent variables, including 50 items.

\begin{tabular}{ccc}
\multicolumn{3}{c}{ TABLE I: SUMMARY OF THE DEPENDENT VARIABLE } \\
\hline Given names & $\begin{array}{c}\text { Number of } \\
\text { items }\end{array}$ & $\begin{array}{c}\text { Cronbach's } \\
\text { alpha }\end{array}$ \\
\hline Employee motivation (EMOTIVA) & $5^{*}$ & .776 \\
\hline
\end{tabular}

* All items have factor loadings $\geq 0.5$

KMO index $=.826$ and Sig. of Bartlett's test $=.000$

Total variance explained $=52.8 \%$

TABLE II: SUMMARY OF THE INDEPENDENT VARIABLES

\begin{tabular}{lcc}
\hline \multicolumn{1}{c}{ Given names } & $\begin{array}{c}\text { Number } \\
\text { of items }\end{array}$ & $\begin{array}{c}\text { Cronbach's } \\
\text { alpha }\end{array}$ \\
\hline Charismatic Leadership (CHARILEAD) & $8^{*}$ & .896 \\
Change-oriented Leadership (CHANORLE) & $7 *$ & .908 \\
Autocratic Leadership (AUTOLEAD) & $7 *$ & .875 \\
Relation-oriented Leadership (RELORLE) & $6^{*}$ & .882 \\
Ethical Leadership (ETLEAD) & $6^{*}$ & .856 \\
Task- oriented relationship (TASKORLE) & $6^{*}$ & .714 \\
Ethic contingent reward Leadership (ETCORELE) & $3 *$ & .813 \\
Participative Leadership (PARTLEAD) & $3^{*}$ & .711 \\
\hline
\end{tabular}

* All items have factor loadings $\geq 0.5$

KMO index $=.906$ and Sig. of Bartlett's test $=.000$

Total variance explained $=61.4 \%$

As illustrated in the Table I, for the dependent variable, the KMO index was at $.826>.05$ and the Sig. of Bartlett's test was at $.000<.05$, this revealed that the data of dependent variable was appropriate for factor analysis. There was one component extracted which corresponded to the concept of employee motivation. Five out of nine items had high factor loadings which were greater than .05 reflecting the high correlation between each item and the corresponding extracted component. The Eigenvalues of the extracted component was at 2.640 satisfying the requirements of being greater than 1 and the total variance explained was $52.8 \%$ of the total variance. In addition, the high value of Cronbach's Alpha of .776 indicated good reliability of the measurement scale for assessing the dependent variable.

Regarding independent variables in Table II, the KMO index was at .906 $>.05$ and the Sig. of Bartlett's test was at $.000<.05$ inferring that the data of independent variables was appropriate for factor analysis. Eight components were extracted corresponding to the concepts of charismatic leadership, change oriented leadership, autocratic leadership, relation oriented leadership, ethical leadership, ethic based contingent reward leadership, and participative leadership in the research model. The Eigenvalues of all extracted components were greater than 1 and the total variance explained was $61.4 \%$ of the total variance. In addition, the values of Cronbach's Alpha of all factors ranging from .711 .908 implying the high reliability of the measurement scale for assessing the independent variables.

\section{RESEARCH FINDING}

\section{A. Sample Descriptions}

TABLE III: PROFILE OF RESPONDENTS

\begin{tabular}{llcc}
\hline & & TABLE III: PROFILE OF RESPONDENTS & \\
\hline Job position & Staff & Frequency & Percent \\
& Low manager & 80 & 70.3 \\
& Middle manager & 15 & 25.0 \\
& Male & 168 & 5.7 \\
\hline Gender & Female & 152 & 47.5 \\
\hline Marital status & Single & 225 & 70.3 \\
& Married & 95 & 29.7 \\
\hline Age & $18-25$ & 39 & 12.2 \\
& $25-35$ & 129 & 40.3 \\
& $35-45$ & 83 & 25.9 \\
\hline Seniority & Less than 1 year & 8 & 2.5 \\
& $1-4$ years & 31 & 9.7 \\
& $4-7$ years & 102 & 31.9 \\
& $7-10$ years & 124 & 38.8 \\
& Over 10 years & 55 & 17.2 \\
\hline Education & Vocational School & 2 & .6 \\
attainment & College & 209 & 65.3 \\
& University & 95 & 29.7 \\
& Post University & 14 & 4.4 \\
\hline
\end{tabular}

\begin{tabular}{|c|c|c|c|c|c|c|c|c|}
\hline & $\begin{array}{l}\text { EMO } \\
\text { TIVA }\end{array}$ & 1 & 2 & 3 & 4 & 5 & 6 & 7 \\
\hline 1. CHARILEAD & $.661 *$ & 1.00 & & & & & & \\
\hline 2.CHANORLE & $.592 *$ & $.579 *$ & 1.00 & & & & & \\
\hline 3.AUTOLEAD & $.212 *$ & $.92 *$ & $.132 *$ & 1.00 & & & & \\
\hline 4.RELORLE & $.664^{*}$ & $.627 *$ & $.589 *$ & $.152 *$ & 1.00 & & & \\
\hline 5.ETLEAD & $.608^{*}$ & $.552 *$ & $.601 *$ & $.083^{*}$ & .640 & 1.00 & & \\
\hline 6.TASKORLE & $.211 *$ & $.056^{*}$ & $-.067 *$ & $.004 *$ & $.089 *$ & $.074^{*}$ & 1.00 & \\
\hline 7.ETCORELE & $.632 *$ & $.591 *$ & $.593 *$ & $.018^{*}$ & $.564 *$ & $.518^{*}$ & $.440 *$ & 1.00 \\
\hline 8.PARLEAD & $.542 *$ & $.508^{*}$ & $.443^{*}$ & $.133^{*}$ & $.489 *$ & $.536^{*}$ & $.029 *$ & $.467 *$ \\
\hline Mean & 3.55 & 3.58 & 3.69 & 2.53 & 3.65 & 3.56 & 3.77 & 3.68 \\
\hline SD & .400 & .443 & .470 & .467 & .474 & .448 & .4696 & .5024 \\
\hline
\end{tabular}

Table III presented the characteristics of the respondents participating in this study. As can be seen from the table, the number of male and female respondents was nearly equal, and the majority of the respondents was staff (70.3\%) and followed by low manager and middle manager with $25 \%$, $4.7 \%$ respectively. Moreover, most of the employees participating in answering the questionnaire were experienced with 7-10 years of working (accounting for $38.8 \%$ the total) in 
the observed organization; most of them graduated from college $(65.3 \%)$. Besides, there were 225 respondents were single and the age from 25-35 took the largest quantity in 320 respondents

\section{B. Factors Correlating with Employee Motivation}

As shown in Table IV, there are positive correlations between all leadership behaviors and EMOTIVA: REORLE $(r=.664)$, CHARILEAD $(r=.661)$, ETCORELE $(r=.632)$, ETLEAD $(r=.608)$, CHANORLE $(r=.592)$, PARLEAD $(r=$ $.542)$, AUTOLEAD $(r=.212)$, and TASKORLE $(r=.211)$. This means that better use of relation-oriented leadership, charismatic leadership, ethic-based contingent reward leadership, ethical leadership, change-oriented leadership, participative leadership, autocratic leadership, and task-oriented leadership behaviors would lead to higher employees' motivation.

\section{Factors Affecting on Employee Motivation}

TABLE V: COEFFICIENTS BETWEEN DEPENDENT VARIABLE AND INDEPENDENT VARIABLES

\begin{tabular}{|c|c|c|c|}
\hline Variables & $\begin{array}{c}\text { Standardized } \\
\text { Coefficients (Beta) }\end{array}$ & Sig. & $\begin{array}{c}\text { Correlation } \\
\text { (Part) }\end{array}$ \\
\hline CHARILEAD & $.222 *$ & .000 & .661 \\
\hline CHANORLE & $.084 *$ & .081 & .592 \\
\hline AUTOLEAD & $.122 *$ & .000 & .212 \\
\hline RELORLE & $.174 *$ & .001 & .664 \\
\hline ETLEAD & $.169 *$ & .001 & .608 \\
\hline TASKORLE & $.170 *$ & .000 & .211 \\
\hline ETCORELE & $.191 *$ & .000 & .632 \\
\hline PARLEAD & $.105 *$ & .013 & .542 \\
\hline
\end{tabular}

*Coefficient is significant at the .05

Dependent Variable: EMOTIVA

Predictors: CHARILEAD, CHANORLE, AUTLEAD, RELORLE, ETLEAD, TASKORLE, ETCORELE, PARLEAD

ANOVA: $F=75.503$, Sig. $=.000$

Model summary: Adjusted R Square $=.645$

As indicated in the table $\mathrm{V}$ above, except CHANORLE had Sig. of $p=.081>.05$, the rest independent variables significantly contributed in predicting EMOTIVA. This means that every 1-standard deviation increase in CHARILEAD, or AUTOLEAD, or RELORLE, or ETLEAD, TASKORLE, or ETCORELE, or PARLEAD would lead to an increase in EMOTIVA of .222, or .122, or .174, or .169, or .170 , or .191 , or .105 , respectively when other leadership behaviors were controlled for. Thus, hypothesis $\mathrm{H}_{3}$ was rejected and other hypotheses including $\mathrm{H}_{1}, \mathrm{H}_{2}, \mathrm{H}_{4}, \mathrm{H}_{5}, \mathrm{H}_{6}$, $\mathrm{H}_{7}, \mathrm{H}_{8}$ were supported by the data at $95 \%$ level of confidence. The regression equation illustrated the effects of leadership behaviors/styles on employee motivation using the standardized coefficients beta $(\beta)$ as followed:

EMOTIVA $=.222$ CHARILEAD +.122 AUTOLEAD + .174 RELORLE + .169 ETLEAD + .170 TASKORLE + .191 ETCORELE + .105 PARLEAD

\section{DisCUSSIONS AND RECOMMENDATIONS}

With the highest value of Beta $(\beta=.222)$, the charismatic leadership was the most influential factor which had the strongest positive impact on the level of employee motivation. According to [42], the significant correlation between followers' preferences for leadership styles can be predicted via values and personality of one leader. Besides, the authors mentioned that when a leader can attract many followers attention, those people will have strong motivation in job, and they are able to perform well under the supervision of that leader, and have more positive work attitudes. Briefly, the great contribution of charismatic leadership in employee motivation is reasonable. Thus, a leader in auditing field should consider following suggestions to boost charismatic leadership impacts on employee motivation. Firstly, "build a foundation for charisma", each leader must first possess a high degree of self-confidence, which is very necessary foundation to achieve effectively every other factors in leadership charisma. Next, "create goals for job", defining goals is important for the sake of clarity. Losing sight of vision is easy, so establish clear reachable goals will serve to renew visions when some problems get tough. Then, "communication", charisma is all about communication one-on-one, or in small groups with team members, so a leader should get those staff together to discuss interdependencies and project goals. To foster the charismatic appeal in other members' eyes, a leader should build a two way bond that every member will involve and let them know that any their achievements will be recognized and congratulated via frequent feedbacks and reviews.

Next, ethic based contingent reward leadership was the second influential factor $(\beta=.191)$ which has a relative strong impact on the level of employee motivation. Under ethic based contingent reward leadership, leaders adopt a consultative style for making decisions, consult individual followers to different degrees, and the leader decide the final decisions. Besides, a close relationship between a leader and his staff is constructed and motivated through the rewards, agreements, and expectations negotiated with the leader [43]. Hence, to improve this leadership style, it is advisable for a leader to do subsequent ways. First, leaders should have clear goals to achieve targets, and provide explicit guidance to other members regarding what they expect from organizational members and how they will be rewarded for their efforts and commitment. Besides, during the process, leader should establish a clear constructive feedback on performance in order to increase the efficiency of established routines and procedures that will help the organization become efficient and productive. Lastly, respond to deviations from expected outcomes and identify corrective actions to improve performance is also important for leader.

Relation oriented leadership with $\beta=.174$ will be discussed because of it moderate influence on employee motivation. In term of this leadership style, employees have many opportunities to involve in skills building and fostering mutually cooperative relations lead to higher employees motivation and higher performance; in turn a leader giving praise for work accomplishments, show appreciation to subordinates for their contributions and achievements [44]. Thus, employees will be motivated highly in the "relation oriented leadership" environment. It is advisable for leaders to follow those steps to improve employee motivation. First, to stimulate employees, aparting from achieving goals and targets, a leader who applies relation oriented leadership also pays attention to create a positive relationship with his subordinates as well as bring friendly atmospheres that make 
employees feel comfortable and easy to speak out their thought. Besides, welfare, caring, encouraging, motivating, developing, and supporting of each individual receives high priority from a leader.

Other leadership behaviors, including task-oriented leadership, ethical leadership, autocratic leadership, and participative leadership with $\beta=.170, .169, .122$ and .105 respectively, will be discussed in term of methods to improve employee motivation.

About task-oriented leadership, it is completely different with relation-oriented leadership. Task-oriented leadership means a leader emphasize strongly on competing task and deadlines. He tends to establish clearly defined schedules, task assignments and deadlines through a structured workplace, in which he requires all tasks that have to be done perfectly. Moreover, a leader will give more suggestions, and takes the high control in workplace to make sure everything run smoothly. His focus is always the task and because of this attitude, task-oriented leadership can be confused with autocratic leadership [45]. The approach is, however, much different, a leader sees potential development of his team as a part of the task whereas, the autocratic leadership look at himself before others and that includes even his team. Due to those specific characteristics of task-oriented leadership, there are some relevant suggestions for a leader to apply and motivate his employees. First, as mentioned before, Task-oriented leaders have a strong orientation for getting the job done and on time. Clearly, a leader should set out work schedules with requirements and deadlines that will be easy for all his staff to follow. Besides, within "task oriented leadership" environment, a leader should pay much attention to follow all tasks to measure the progress. In addition, task-oriented leadership works especially well in environments where job responsibilities are more easily defined and predictable. Next, establishing and maintaining a high standard for performance is necessary. A leader shows his expectancies to employees, which he requires the desired results in the strict schedules and brings efficiency in production. Finally, a leader will be not only control his employees' performance, but he also should know what is going on and stay in touch with the company, clients, suppliers, etc., information. If a leader runs a section without ideas of what is happening in other sections or the direction the company is headed, then he cannot keep pace with other leaders' achievements.

Regarding to ethical leadership, [46] proposed that ethical leadership based on elements involving effective social learning, which mean leaders influence followers' ethical conduct through role modeling. Besides, the more moral leaders are in their business dealings, the more handshakes from employees a leader can have, the more the wheels of capitalism work better because of trust in the marketplace. Business ethics bring benefits for both sides." [47]. Hence, there are some concrete steps about how best to develop ethical leaders and stimulate employees effectively. Frist of all, a leader should create a trust environment with employees where they feel free to discuss ethical dilemmas and issues with their leader. Second, a leader can establish a shared ethical vision with other group members form various levels of the team and build a "Code of Conduct" that will spread out the ethical vision of the organization to staff. Next, a leader should ensure that established vision and code is communicated to everyone within the organization, which can be controlled through, for example, policy manuals, training events, one-on-one and team coaching, newsletters, team meetings, etc.. Besides, communication channel program between a leader and his staff is another important success suggestion. Within the channel program, employees will communicate easily their concerns back to management in a safe and confidential manner. Lastly, a leader should be an ethical pioneer that means he will be a first person raising voice to against unethical behavior, all violators of ethical standards must be punished equally and justly throughout the organization.

About autocratic leadership situation, we should recognize and have a suitable interpretation. As mentioned in the $\mathrm{H}_{6}$ as "autocratic leadership negatively affect employee motivation", but in the reality, autocratic leadership positively affected employee motivation with $(\beta=.122, p=.000)$, so $\mathrm{H}_{6}$ was not supported. However, this result still can be accepted and explained well in the exceptional situation that requires urgently completed tasks without considering staff opinions; or when decisions need to be made quickly and some projects require strong leadership to get things accomplished briskly and efficiently. Hence, in the scope of this research, it can be inferred that in 320 auditors we survey, there are some auditors have to complete urgent tasks without too much discussion with their leaders. Because of relevant literature review, this result supported the arguments made by Delia, Novi and Serbia (2013) [48].

Lastly, participative leadership is defined as a mastermaster relationship with group members in whom a leader will develop his leadership abilities by consulting and encouraging employees' participation in decision-making. A leader focused highly on group participation, discussion, and group decisions [49]. Besides, because of participative leadership impacts on employees' motivation, a leader can follow some suggestions to make sure that everybody has a say and that decisions are made as well as gain more benefits from this leadership style. First of all, a leader should create and improve the morale of a workplace that help employees feel engaged with the company whenever they contribute ideas, or business decisions, activities. When employees feel like their role is less submissive and restricted, they have less of a tendency to withdraw and more focus on task completion. In addition, they are more opened to share views, discuss perspectives on those ideas freely before making decisions. Moreover, they have the sense that they are also key stakeholders in the evolution of the department or company. Besides, innovative contributions relate to ideas, actions, products, etc., of employees should be recognized quickly and let those employees realize that their ideas and feedback are not only appreciated, but also often put into action; and in turn, they receive reward.

\section{CONCLUSIONS}

All the research objectives have been fully achieved. Firstly, the study has determined completely eight suitable leadership styles that have potential impacts on employee 
motivation. Secondly, the regression equation demonstrating the relationship between leadership styles and employee motivation is found out successfully. Finally, to promote the high level of employee motivation at workplace (auditing field), the research findings and the study also have provided the directions for leaders to manipulate their leadership styles.

The study has both theoretical and practical contributions to the fields of leadership styles and employee motivation. The Results from the study emphasize that compensations, fringe benefits/rewards can be important elements, but characteristics/personalities of a leader is the most decisive factor that creates an effective motivational work environment for the staff, which leads to a positive job attitudes.

However, the study has limitations in its research scope. There is a possibility that the results were biased against the auditors working in Ho Chi Minh City. Therefore, it is recommended to conduct further studies with other auditors in different areas to test the generalizability of leadership styles and employee motivation.

\section{REFERENCES}

[1] S. Khan, "The key to being a leader company: Empowerment," Journal for Quality and Participation, vol. 20, no. 2, pp. 44-53, 1997.

[2] T. Watson, "Linking Employee Motivation and satisfaction to the bottom line," CMA Magazine, vol. 68, no. 3, pp. 4, 1994.

[3] Audit industry. (2014). General audit industry in Vietnam. [Online]. Available:

http://kiemtoan.com.vn/toan-canh-nghe-kiem-toan-doc-lap-hien-nay

[4] C. C. Pinder, Motivation in Work Organizations, Upper Saddle River, NJ: Prentice Hall, 1998.

[5] R. Luomanpaa, "Employee motivation at Tommy Bartlett, Inc," B. thesis, Dept. Applied Sciences, Haaga- Helia Univ., Wisconsin Dells, USA, 2012.

[6] B. E. Bowen and R. B. Radhakrishna, "Job satisfaction of agricultural education faculty: A constant phenomena," Journal of Agricultural Education, vol. 32, no. 2, pp. 16-22, 1991.

[7] S. Ramlall, "A review of employee motivation theories and their implications in employee retention within organizations," Journal of American Academy of Business, Cambridge, vol. 5, pp. 52-63, 2004.

[8] A. Reena, "The impact of reward and recognition probrams on employee's motivation and satisfaction: An emprical study," International Review of Business Research Papers, vol. 5, no. 4, pp. 270-279, 2009.

[9] S. K. Singh, T. Vivek, "Relationship between motivation and job satisfaction of the white collar employees," Journal of SMS Varanasi, vol. 7, no. 2, pp. 31-39, 2011.

[10] R. M. Stogdill, "Leadership, membership and organization," Journal of Psychological Bulletin, vol. 1, no. 14, pp. 47, 1950.

[11] R. J. House, "Path-goal theory of leadership: Lessons, legacy, and a reformulated theory," Journal of the Leadership Quarterly, vol. 7, pp. 323-352, 1996.

[12] P. Hersey and K. Blanchard, "Life-cycle theory of leadership," Journal of Training and Development, vol. 23, pp. 26-34, 1969.

[13] S. Kerr, M. Jermier, "Substitutes for leadership - Their meaning and measurement," Journal of Organizational Behavior and Human Performance, vol. 22, pp. 375-403, 1979.

[14] G. Yukl, Leadership in Organizations, $5^{\text {th }}$ ed. Prentice-Hall Inc, 2002.

[15] J. E. Higgins and N. Endler "Coping, life stress, and psychological and somatic distress," European Journal of Personality, vol. 9, pp. 253-270, 1995.

[16] D. L. Causey and E. F. Dubow, "Negotiating the transition to junior high school: The contributions of coping strategies and perceptions of the school environment," Journal of Prevention in Human Services, vol. 10, pp. 59-81, 1993.

[17] B. E. Compas, V. L. Malcarne, and K. M. Fondacaro, "Coping with stressful events in older children and young adolescents," Journal of Consulting and Clinical Psychology, vol. 56, pp. 405-411, 1988.

[18] B. Bass, Bass \& Stogdill's Handbook of Leadership, $3^{\text {rd }}$ ed. New York: The Free Press, 1990.
[19] B. M. Bass, "From transactional to transformational leadership: Learning to share the vision," Journal of Organizational Dynamics, vol. 18, no. 3, pp. 19-31, 1990.

[20] B. M. Bass, B. J. Avolio, and D. I. Jung, "Re-examining the components of transformational and transactional leadership using the multifactor leadership," Journal of Occupational and Organizational Psychology, vol. 72, pp. 441-462, 1999.

[21] G. Yukl, A. Gordon, and T. Taber, "A hierarchical taxonomy of leadership behavior: Integrating a half century of behavior research," Journal of Leadership and Organizational Studies, vol. 9, pp. 15-32, 2002.

[22] E. Fleishman and E. Harris, "Patterns of leadership behavior related to employee grievances and turnover," Journal of Personnel Psychology, vol. 15 , pp. 43-56, 1962.

[23] J. Butler, S. Cantrell, and R. Flick, "Transformation leadership behaviors, upward trust, and satisfaction in self-managed work teams," Journal of Organization Development, vol. 17, no. 1, pp. 13-25, 1990

[24] G. Yukl, Leadership in Organizations, $7^{\text {th }}$ ed. Englewood Cliffs, NJ: Prentice hall, 2010.

[25] A. Skogstad and S. Einarsen, "The importance of a change-centred leadership style in four organizational cultures," Scandinavian Journal of Management, vol. 15, pp. 289-306, 1999.

[26] P. L. Koopman and A. F. M. Wierdsma, "Participative management," Personnel Psychology: Handbook of Work and Organizational Psychology, Hove, UK: Psychology Press, 1998, vol. 3, pp. 297-324.

[27] R. Nader. (1988). Leadership and motivation. [Online]. Available: http://www.ibrd.gov.nl.ca/regionaldev/lm.pdf

[28] M. A. Smylie, V. Lazarus, and J. Brownlee-Conyers, "Instrumental outcomes of school-based participative decision making," Journal of Educational Evaluation and Policy Analysis, vol. 18, pp. 181-191, 1996.

[29] A. Somech, "Explicating the complexity of participative management: an investigation of multiple dimensions," Journal of Educational Administration Quarterly, vol. 38, pp. 341-371, 2002.

[30] J. A. Scully, S. A. Kirkpatrick, and E. A. Locke, "Locus of knowledge as a determinant of the effect of participation on performance, affect, and perceptions," Journal of Organizational Behavior and Human Decision Processes, vol. 61, pp. 276-288, 1995.

[31] E. A. Locke and P. G. Latham, A Theory of Goal Setting and Task Performance, Englewood Cliffs, New Jersey: Prentice-Hall, 1990.

[32] A. A. Armenakis, S. G. Harris, and K. W. Mossholder, "Creating readiness for organizational change," Journal of Human Relations, vol. 46, pp. 681-703, 1993.

[33] B. M. Bass, Leadership and Performance beyond Expectations, New York: Free Press, 1985.

[34] S. P. Robbins, T. A. Judge, A. Odendal, and G. Roodt, Organisational Behaviour: Global and South African Perspectives, $2^{\text {nd }}$ ed. Cape Town: Pearson Education, 2009.

[35] D. C. McClelland, Power: The Inner Experience, $2^{\text {nd }}$ ed. New York: Irvington, 1975.

[36] R. J. House and J. M. Howell, "Personality and charismatic leadership," Journal of the Leadership Quarterly, vol. 3, pp. 81-108, 1992.

[37] M. E. Brown, L. K. Treviño, and D. A. Harrison, "Ethical leadership: A social learning perspective for construct development and testing," Journal of Organizational Behavior and Human Decision Processes, vol. 97, pp. 117-134, 2005

[38] R. N. Kanungo, "Ethical values of transactional and transformational leaders," Canadian Journal of Administrative Sciences, vol. 18, pp. 257-265, 2001.

[39] K. S. Cameron, J. E. Dutton, and R. E. Quinn, Positive Organizational Scholarship: Foundations of a New Discipline, San Francisco: Berret-Koehler, 2003.

[40] B. M. Bass and P. Steidlmeier, "Ethics, character, and authentic transformational leadership behavior: A systematic analysis of issues, alternatives, and approaches," Journal of Leadership Quarterly, vol 10, no. 2, pp. 181-217, 1990

[41] K. S. Sheldene, B. Juian, and T. Nick, "Transformational leadership and leader moral orientation: contrasting an ethic of justice and an ethic of care," Journal of the Leadership Quarterly, vol. 21, pp. 179-188, 2010.

[42] M. G. Erthart and K. J. Klein, "Predicting followers' preferences for charismatic leadership: The influence of follower values and personality," Journal of the Leadership Quarterly, vol. 12, pp. 153-179, 2001.

[43] G. C. Avery and H. Bergsteiner, Honeybees \& Locusts: The Business Case for Sustainable Leadership, Sydney: Allen \& Unwin, 2004, 2010. 
[44] A. J. Li, S. K. Soriano, and K. M. Martinez, "Locus of knowledge as a determinant of the effect of participation on performance, affect, and perceptions," Organizational Behavior and Human Decision Processes, vol. 61, pp. 276-288, 2007.

[45] K. Neil, The Strengths \& Weaknesses of a Task-Oriented Leadership Style, New York: Demand Media, 2014.

[46] B. E. Michael and K. T. Linda, "Ethical leadership: A review and future directions," Journal of the Leadership Quarterly, vol. 17, pp. 595-616, 2006

[47] S. Rick. (2014). Brainy quote. Ethics Quotes at Brainy Quote. [Online]. Available: http://www.brainyquote.com/quotes/keywords/ ethics_4.html

[48] B. Delia, S. Novi, and S. Serbia, "Leadership Styles and creativity," Journal of Applied Knowledge Management, vol. 1, pp. 64-75, 2013.

[49] N. Babak, "The Impact of participative leadership on employee's motivation, job satisfaction and innovation," Ph.D. dissertation, Dept. Business, British Univ., Dubai, 2012.

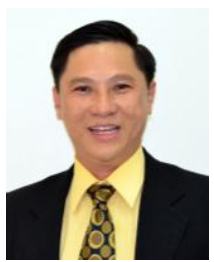

Mai Ngoc Khuong is a lecturer and researcher of School of Business Administration, International University, Vietnam National University, Ho Chi Minh City. He has a bachelor degree in tourism and hospitality management, a master of science degree in leisure, tourism and environment at Wageningen University, The Netherlands, and a $\mathrm{PhD}$ degree in development management at School of Public Administration of the National Institute of Development Administration (NIDA), Bangkok, Thailand.

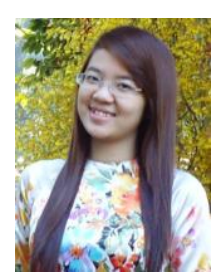

Dang Thuy Hoang is a research assistant of School of Business Administration, International University, Vietnam National University, Ho Chi Minh. She has a bachelor degree in business administration at International University, Vietnam National University, Ho Chi Minh. She is specialized in international business management and interested in international marketing, import-export management and strategic management. In fall semester of 2015, she attends the courses of master of science in leadership provided by The Twinning Program between International University (IU) and Northeastern University (NU). 